\title{
Bahçe Temelli Öğrenme Yaklaşımına Yönelik Eğilimler: Okul Bahçesi Uygulamaları Örneği (2000-2015)
}

\section{Mustafa ÜREY*}

Öz: Yapılan çalışmanın amacı, okul bahçesi uygulamalarının içerik analizini yaparak, bahçe temelli öğrenme yaklaşımına yönelik eğilimleri ortaya koymaktır. 2000-2015 yılları arasında 21 farklı dergide tam metin olarak yayımlanan 162 makale çalışmanın kapsamını oluşturmaktadır. İlgili makaleler, araştırmacı tarafından geliştirilen "Okul Bahçesi Uygulamaları Alan Tarama Formu" kullanılarak betimsel içerik analizine tabi tutulmuştur. Analiz sonuçlarına göre, okul bahçesi uygulamaları kapsamında gerçekleştirilen çalışmalarda daha çok akademik performansın belirlenmesi ve geliştirilmesi ile birlikte sağlıklı yaşam becerilerinin geliştirilmesi hedeflenmiştir. Yapılan araştırmalarda kullanılan araştırma modelleri incelendiğinde daha çok belirli bir araştırma modeli kullanılmadığı, kullanılanlarda ise deneysel araştırma modelinin ağırlık kazandığı görülmektedir. Örneklem olarak özellikle okul öncesi ve ilköğretim düzeyindeki öğrencilere yer verilirken, nicel ve nitel veri toplama araçlarına yer verildiği tespit edilmiştir. Okul bahçesi uygulamalarının sonuçları incelendiğinde ise akademik performansın gelişimi, sağlıklı yaşam becerilerinin gelişimi ve bireysel ve sosyal becerilerinin gelişimi üzerinde olumlu bir etkiye sahip olduğu tespit edilmiştir.

Anahtar Kelimeler: Okul dışı öğrenme ortamları, bahçe temelli öğrenme, okul bahçesi, içerik analizi

\section{Trends of Garden Based Learning Approach: Example of School Garden Applications} (2000-2015)

Abstract: The aim of the study is to analyze the content of school gardening practices and to identify trends towards a garden-based learning approach. The scope of the study is composed of 162 articles published in full text in 21 different journals between 2000 and 2015 . The related articles were subjected to descriptive content analysis using the "School Garden Practices Survey Form (SGPSF)" developed by the researcher. According to the results of the analysis,

\footnotetext{
* Dr. Öğr. Üyesi, Trabzon Üniversitesi, Fatih Eğitim Fakültesi, Matematik ve Fen Bilimleri Eğitimi Bölümü, Email: murey01@gmail.com, Orcid No: 000-0002-7753-7936.
}

\begin{tabular}{lll}
\hline Gönderim:20.07.2018 Kabul:21.08.2018 & Yayın:20.10.2018
\end{tabular}


it is aimed to develop healthy living skills with the determination and development of academic performance in studies conducted within the scope of school garden practices. When the research models used in the researches are examined, it is seen that a specific research model is not used and the experimental research model is preferred. It has been determined that quantitative and qualitative data collection tools are used in the sample, especiallypre-school and primary school students are included. When the results of school gardening practices are examined, it has been found that they have a positive effect on the development of academic performance, the development of healthy living skills, and the development of individual and social skills.

Keywords:Outdoor learning environments, garden-based learning, school gardening, content analysis

\section{Giriş}

Zamana ve toplumun ihtiyaçlarına göre şekillenen eğitim-öğretim faaliyetleri son yıllarda hızlı bir değişim içerisine girmiş ve yapılan reformlarla birlikte günümüzde yeni anlamlar kazanmıştır. Özellikle bilim ve teknolojide meydana gelen baş döndürücü gelişim ve değişimler mevcut eğitim felsefelerinin değişmesini gerektirmiş, öğretim yöntem ve tekniklerinden başlayarak nelerin, nerede, nasıl öğretileceğine kadar pek çok konunun gözden geçirilmesine neden olmuştur. Eğitim-öğretim uygulamalarında kullanılan yöntem, teknik ve araç-gereçlerle birlikte öğrenme ortamları da değişime zorlanmıştır. Ülkemizde son yıllarda sıkça yapılan program değişiklikleri dikkate alındığında, eğitim-öğretim faaliyetlerinin artık sadece sınıf içi ortamlar olmaktan çıktığı ve sınıf ve okul dışı öğrenme ortamlarına ihtiyaç olduğu sonucuna ulaşılmıştır (Aydın, Bakırcı ve Ürey, 2012). Okul ve sınıf dışı öğrenme ortamları, öğrenmenin sadece bireysel bir faaliyet olarak sınıf içinde değil, yaşamın her alanında gerçekleştirilebileceği tezine dayanmaktadır. Uygulama alanları olarak ise formal öğrenmeye destek olabilecek ve okul imkânları gözetilerek oluşturulmuş ya da seçilmiş öğrenme ortamları işaret edilmektedir.

Bahçe temelli öğrenme yaklaşımı bağlamında okul ya da sınıf dışı öğrenme ortamı olarak kullanılan merkezler hayvanat bahçeleri, botanik bahçeleri ve okul bahçeleridir (LaçinŞimşek, 2011; Ürey, 2013). Hayvanat bahçeleri, yabani ve evcil hayvanların teşhiri için düzenlenmiş park alanları iken; botanik bahçeleri, bitki grupları arasındaki akrabalık ilişkilerini yansıtacak biçimde düzenlenen doğal yaşam ve öğrenme alanlarıdır (Balkan Kıyıcı, 2010). 
Okul bahçeleri ise; “Kökeni bahçe temelli öğrenmeye dayanan, öğrencilerin kendilerinin tasarlayarak oluşturduğu, okul sahası içerisinde yer alan ve üzerinde çeşitli ürünlerin yetiştirildiği planlı ve programlı bahçe tarımı faaliyetleri (Miller, 2005, s.49)" şeklinde tanımlanmaktadır. Okul bahçesi uygulamaları kapsamında, bitki yetiştiriciliği ile birlikte hayvan yetiştiriciliğinin de yapıldığı bilinmektedir. Kuş gözlem evleri aracılığıyla kuş gözlemlerinin, ipek böceği yetiştiriciliğinin ve kümes hayvanların yetiştirildiği okul bahçesi uygulamalarına da rastlamak mümkündür (Ürey, 2013).

Bahçe temelli öğrenme yaklaşımının bir parçası olan okul bahçesi uygulamaları aslında yeni bir olgu olmayıp, 19. yüzyılın başlarındaözellikle çocukların gelişimi için kullanılan Batı Avrupa kökenli bir uygulama olarakdoğmuştur. 1837 yılında çocukların deneyimleri sonucu öğrenebileceğini savunan Almaneğitimci Friedrich Froebel literatürde "çocuk bahçesi” anlamına gelen "kinder garten" ilebağlantı kurarak okul bahçesi uygulamalarına öncülük etmiştir (Shair, 1999). Okul bahçesiuygulamaları 19. yüzyılın sonlarına doğru 1891 yılında Amerika'ya taşınarak,Massachusetts'de "Massachusetts Horticultural Society" sponsorluğunda "Boston'sPuntom School” da yürütülmeye başlanmıştır (Greene, 1910; Akt. Klemmer, Waliczek ve Zajicek, 2005a).1900’lü yılların başlarında John Dewey gibi gelişimci araştırmacıların öğrenme hakkındaortaya attığı teoriler aracılığıyla okul bahçesi uygulamaları hız kazanmaya başlamıştır. Buçalışmalar sadece okul ortamları ile sınırlı tutulmayıp toplumun farklı kademelerinde dehissedilir bir şekilde uygulamaya geçmiştir (Harlen ve Simon, 2001; Kohlstedt, 2008).Okullarda ve toplumun farklı kademelerinde uygulanan bu çalışmalar başlangıçta bireyterapisinin ve tarım eğitiminin bir parçası olarak ele alınırken, I. ve II. Dünya savaşlarındabitkisel ve hayvansal besin üretim merkezleri olarak kullanılmaya başlanmıştır. Amerika' da disiplinler arası çokamaçlı olarak kullanılan bu çalışmalar son 30 yıl içerisinde öğretim programlarına yerleştirilerekbütün okullarda ve üniversitelerde yaygın hale getirilmiştir (Blair, 2009; Dirks ve Orvis,2005; Ozer, 2007). Özellikle ilköğretim düzeyinde bu çalışmalara bağlı olarak 1978'de“Life Lab K-5 Science Program”, 1990'da “GrowLab Curricula”, 1995'de “Texas A\&M'sJunior Master Gardener Program”, 2003'te "New York's Curriculum Kids Growing Food" ve 2013'te "UC Davis' Curriculum Nutrition to Grown On" ve "School Gardening Program" gibi programlar geliştirilmiş olup, bu programlarayönelik kazanımlar üzerinde çalışmalar (Brynjegard, 2001; Bundschu-Money, 2003;DeMarco, Relf ve McDaniel, 1999; Ürey, 2013; Çepni, Aydın, Haşıloğlu ve Ürey, 2011; Hazzard, Moreno, Beall ve Zidenberg-Cherr, 2011) halen devam etmektedir.Özellikle Amerika ve Avustralya gibi çok 
kültürlü toplumlarda rağbet gören bu program geliştirmeçalışmaları ile farklı kültürlere sahip bireylerin kültürel entegrasyonu sağlanmayaçalışılarak, toplumsal uyum problemleri de aşılmaya çalışılmıştır (Cutter-Mackenzie, 2009;Kane, 2004; Tangen ve Fielding-Barnsley, 2007). Bunun dışında, okul bahçesi uygulamaları ile farklı disiplinlerdeki akademik başarılar, çevresel farkındalık, derslere yönelik tutumlar, sağlıklı yaşam ve beslenme alışkanlıkları, sosyal ve bireysel beceriler üzerine odaklanıldığı görülmüştür. Son yıllarda, özellikle çevresel sürdürülebilirliği destekleyen, öğrencilerin sosyal problemlerini en aza indirgeyen, farklı kültürlerdeki öğrencileri bir potada kaynaştıran bir pedogojik yaklaşıma ihtiyaç duyan öğretmenler için okul bahçesi uygulamalarının çok uygun bir yöntem olduğu araştırmaların ortak fikri olarak karşımıza çıkmaktadır (Akinyemi, Fragstein ve Agnew, 2008; Ürey, 2013).

Okul bahçeleri öğrencilerin yakın çevreleri ilefiziksel etkileşime girdiği güçlü bir deneysel öğrenme ortamı sunmaktadır. Öğrenciler,böyle bir ortamda yaparak ve yaşayarak ilk elden deneyimler yaşamakta ve sorunlarıyerinde görerek çözümler önerebilmektedirler (Maloof, 2006). Bir okul bahçesitasarlayarak, kendi öğrenme alanlarını oluşturan ve bu ortamdan ürün elde edenöğrenciler güncel yaşam problemleri ile daha rahat mücadele etmekte ve çözüm yollarıüretebilmektedirler (Bakırcı, Artun ve Deniz, 2018). Böyle bir ortamı kendisi oluşturabilen ve oluşturmuş olduğu buortamdan faydalanabilen öğrencilerin sorumluluk alabilen, kendine güvenen, kendi başınakarar alabilen, kendini ifade edebilen, iletişim becerisi yüksek, eleştirel düşünüpproblemlere çözüm üretebilen bireyler olarak yetiştiği tespit edilmiştir (Damon, 2001; Lownds, 2000). Okul bahçesi uygulamalarının özellikle okul öncesi ve ilköğretimdönemleri için en uygun çalışmalar olduğu ileri sürülmektedir (Thrive, 2006). Özelliklekişilik ve bir takım üst düzey becerilerin gelişimi için bu dönemin en işlenebilir bir dönemolduğu bilinmektedir. Bu dönemlerde okul bahçesi uygulamalarına katılan bir öğrenci hergün yeni bir şeyleri keşfetmekte ve keşfettikleri karşısında bir takım tutum ve becerilergeliştirmektedir (Thrive, 2006). Okul bahçesi uygulamalarının tutum ve becerilerinoluşmasının yanında, öğrencilerin akademik başarılarında ve çevresel farkındalıkdüzeylerinin gelişiminde de etkili olduğu sonucu pek çok araştırma tarafından ilerisürülmektedir. Özellikle okul bahçesi uygulamalarının fen, matematik, edebi sanatlar,sağlık, tarım ve çevre gibi dersler için disiplinler arası bir öğrenme ortamı sunduğu ve buöğrenme ortamlarında ilgili derslere yönelik öğrencilerin tutumlarının (Dirks ve Orvis, 2005; Klemmer, Waliczek ve Zajicek, 2005b; Rahm, 2002; Sparrow, 2008; Ürey ve Çepni, 2014a; Waliczek, Logan ve Zajicek, 2003) ve akademik başarılarının (Klemmer, Waliczek ve Zajicek, 
2005a; Klemmer, Waliczek ve Zajicek, 2005b, Lieberman ve Hoody, 1998; Ürey ve Çepni, 2015; Ürey, Çepni, Köğce ve Yı1dız, 2013; Ürey, Çepni ve Kaymakçı, 2015) olumlu yönde arttığı ifade edilmektedir.Ayrıca, okul bahçesi uygulama sürecinde aile katılımının aktif olarak kullanılıyor olması ve süreçte uzman desteğinin sağlanıyor olması ile öğrencilerin okulu benimsemeleri, disiplin problemlerini en aza indirmeleri ve kariyer bilinçlerini artırmaları yönünde avantajlar sağladığı pek çok araştırma tarafından ifade edilmektedir (Louv, 2008; Lekies ve Sheavly, 2007; Ürey ve Çepni, 2014b).

Çıktıları açısından oldukça geniş bir yelpazeye sahip olan bahçe temelli öğrenme yaklaşımı ve bu yaklaşımın temel alındığı okul bahçesi uygulamaları her geçen gün eğitimöğretim programları üzerindeki etkisini biraz daha artırmaktadır. Özellikle ülkemiz açısından ilkokulda serbest etkinlik çalışmaları ve ortaokulda bilim uygulamaları dersleri ile örtüşebileceği düşünülen bu uygulamaların geçmişten günümüze yansımaları ve son yıllardaki eğilimleri bu tür çalışmaları uygulayacak olan öğretmenlere 1şı tutacaktır. Bu durum, bahçe temelli öğrenme yaklaşımı kapsamında yayınlanan bilimsel makalelerin pek çok ölçüt açısından incelenmesini gerekli kılmaktadır. Bu bağlamda, yapılan çalışma ile okul bahçesi uygulamalarının içerik analizini yaparak, bahçe temelli öğrenme yaklaşımına yönelik eğilimlerin ortaya konması amaçlanmaktadır. Bu amaç kapsamında, 2000-2015 yılları arasında gerçekleştirilen okul bahçesi uygulamalarının amaçları, araştırma modelleri, örneklemleri, veri toplama araçları ve araştırmaların sonuçları incelenmiş ve yıllara göre bu boyutlardaki değişim incelenmeye çalış1lmıştır.

\section{Yöntem}

\section{Araştırma Modeli}

Yapılan çalışmada analitik araştırma yöntemlerinden doküman analizi kullanılmıştır. Doküman analizi, yapılacak çalışma ile ilgili mevcut kayıt ve belgeleri toplayıp belirli bir norm veya sisteme göre kodlama işlemidir. Doküman analizindeki temel amaç, yeni bir bilgi ya da keşfe ulaşmaktan ziyade yapılanlardan yola çıkarak genel eğilimleri ve alternatif düşünce ve fikirleri ortaya koyabilmektir (Çepni, 2010). Doküman analizi meta-analiz, meta-sentez ve betimsel içerik analiziolmak üzere 3 grupta ele alınmaktadır. Yapılan çalışma kapsamında betimsel içerik analizi kullanılmıştır. Betimsel içerik analizi, “Belirli bir konu üzerinde yapılan çalışmaların ele alınıp eğilimlerin belirlenmesi ve araştırma sonuçlarının tanımlayıcı bir boyutta değerlendirilmesini içeren sistematik çalışmalardır" (Çalık ve Sözbilir, 2014, s.34). 
$\mathrm{Bu}$ çalışmada, alan yazında yapılmış olan bilimsel makaleler daha önce araştırmacı tarafından belirlenen ölçütler çerçevesinde analiz edilmiş ve ilgili alan yazındaki eğilimler belirlenmeye çalışılmıştır.

\section{Araştırmanın Kapsamı}

Yapılan araştırmada, ilgili alandan toplam 21 farklı dergide tam metin olarak yayınlanan 154'ü uluslararası, 8'i ulusal toplam 162 bilimsel makaleye ulaşılmıştır. Ulaşılan makaleler 2000-2015 yılları arasında ilgili alan yazında yayınlananbilimsel makalelerdir. Bu makaleler Web of Science, Education Resources Information Center (ERIC), Academic Searh Complete, Google Scholar, Agriculture Journals ve Ulusal Akademik Ağ ve Bilgi Merkezi (ULAKBİM) gibi veri tabanlarından alınmıştır. İlgili veri tabanlarında bahçe temelli öğrenme, okul bahçesi, garden based learning, school garden/ing gibi Türkçe ve İngilizce anahtar sözcükler kullanılarak tarama gerçekleştirilmiştir. Ücretli olan veri tabanlarına Karadeniz Teknik Üniversitesi kütüphanesiüzerinden erişim sağlanırken, ücretsiz ve açık erişimli olanlara ise dergilerin kendi web sayfalarından erişilmiştir.

\section{Veri Toplama Araci}

Yapılan çalışmada, araştırmacı tarafından geliştirilen “Okul Bahçesi Uygulamaları Alan Tarama Formu (OBATF)" kullanılmıştır (EK-1). İlgili form, alan yazındakiiçerik dikkate alınarak oluşturulmuştur. Oluşturulan form, biyoloji eğitimi ve fen bilgisi eğitimi alanlarında uzman iki öğretim üyesi tarafından incelenmiş ve gerekli düzenlemeler sonrasında forma son hali verilmiştir. OBATF, makale künyesi ve makale içeriği olmak üzere iki bölümden oluşmaktadır. Makale künyesi; makalenin adı, yazarları, yayınlandığı derginin adı, yılı, cilt, sayı ve sayfa numaraları ile makalenin ulusal ve uluslar arası boyutu başlıklarından oluşmaktadır. Makalenin içeriği ise makalenin amacı, araştırma modeli, örneklemi, veri toplama araçları, verilerin analizi ve sonuçları başlıklarından oluşmaktadır.

\section{Verilerin Analizi}

İlgili veri tabanlarından ulaşılan makaleler tek tek incelenerek çalışmanın istenilen içeriğe sahip olup olmadığ 1 sorgulanmıştır. Bu ön inceleme sonrasında bazı çalışmaların eğitim boyutunun dışında kaldığı gözlemlenirken, bazı çalışmaların içeriği konusunda tereddütler yaşanmıştır. İlgili tereddütler alan uzmanı iki öğretim üyesine sunulmuş ve anahtar sözcüklerin makale başlı̆̆ içerisinde yer alması gerektiği kriteri dikkate alınarak eleme gerçekleştirilmiştir. Eleme sonrasında toplam 21 farklı dergiden 162 makale çalışma kapsamına dahil edilmiştir. Çalışma kapsamına dahil edilen tüm makaleler numaralandırılarak her bir makale için OBATF 
doldurulmuştur. OBATF üzerindeki veriler çetele yöntemi ile analiz edilmiştir. Makalenin içeriği; amaç, araştırma modeli, örneklem, veri toplama araçları ve sonuçlar başlı̆̆ı altında tema ve kodlar oluşturularak sunulmuştur. Ortaya çıkan tema ve kodlar frekans ve yüzde tabloları ile birlikte grafikler yardımıyla görselleştirilmiştir.

\section{Bulgular}

Bahçe temelli öğrenme yaklaşımı kapsamında kullanılan okul bahçesi uygulamalarının analizinden elde edilen bulgular, araştırmacı tarafından geliştirilen “OBATF”de kullanılan temalar doğrultusunda sunulmuştur. Bu kapsamda, incelenen makalelerin amaçları, kullanılan araştırma modeli, örneklemi, veri toplama araçları, veri analiz yöntemleri ve sonuçları dikkate alınarak bulgular sergilenmiştir.

Bahçe temelli öğrenme yaklaşımı kapsamında kullanılan okul bahçesi uygulamaları “araştırmanın amacı” başlığı altında incelendiğinde, Tablo 1'de sunulan bulgulara ulaşılmıştır.

Tablo 1. Okul Bahçesi Uygulamaları Kapsamında Gerçekleştirilen Çalışmaların Amaçları

\begin{tabular}{|c|c|c|c|}
\hline \multirow{2}{*}{ Temalar } & \multirow{2}{*}{ Kodlar } & \multicolumn{2}{|c|}{$\mathrm{n}=162$} \\
\hline & & $\mathbf{f}$ & $\%$ \\
\hline \multirow{3}{*}{$\begin{array}{l}\text { Rehber materyal geliştirme } \\
(\mathrm{n}=18, \% 11.11)\end{array}$} & Etkinlik geliştirme & 7 & 4.32 \\
\hline & Geliştirilen bir etkinliğin etkisini ölçme & 10 & 6.17 \\
\hline & Ölçek, test, rubrik, kontrol listesi, vb. geliştirme & 3 & 1.85 \\
\hline \multirow{3}{*}{$\begin{array}{l}\text { Program geliştirme } \\
(\mathrm{n}=31, \% 19.14)\end{array}$} & Bağımsız bir program geliştirme & 7 & 4.32 \\
\hline & Mevcut müfredata bağlı entegre bir program geliştirme & 14 & 8.64 \\
\hline & Geliştirilen bir programın etkisini ölçme & 16 & 9.88 \\
\hline \multirow{7}{*}{$\begin{array}{l}\text { Akademik performans belirleme } \\
(\mathrm{n}=43, \% 26.54)\end{array}$} & Fen bilimleri & 24 & 14.81 \\
\hline & Sosyal bilimler & 4 & 2.47 \\
\hline & Matematik & 12 & 7.41 \\
\hline & Görsel sanatlar & 4 & 2.47 \\
\hline & Edebi sanatlar & 11 & 6.79 \\
\hline & Ekoloji & 16 & 9.88 \\
\hline & Sürdürülebilir kalkınma & 5 & 3.08 \\
\hline \multirow{3}{*}{$\begin{array}{l}\text { Sağlıklı yaşam becerileri } \\
\text { geliştirme } \\
(\mathrm{n}=54, \% 33.33)\end{array}$} & Sebze / meyve tercihi ve tüketimi & 25 & 15.43 \\
\hline & Sağlıklı beslenme & 18 & 11.11 \\
\hline & Rehabilitasyon (terapi, kayg1, stres vb.) & 11 & 6.79 \\
\hline \multirow{2}{*}{$\begin{array}{l}\text { Sosyal ve bireysel beceri } \\
\text { geliştirme } \\
(\mathrm{n}=16, \% 9.88)\end{array}$} & $\begin{array}{l}\text { Bireysel beceriler (problem çözme, özgüven, } \\
\text { sorumluluk, motivasyon, girişimcilik) }\end{array}$ & 13 & 8.02 \\
\hline & $\begin{array}{l}\text { Sosyal beceriler (empati, kişilerarası ilişki, katılım, } \\
\text { takım çalışması) }\end{array}$ & 16 & 9.88 \\
\hline
\end{tabular}

Tablo 1 incelendiğinde, okul bahçesi uygulamalarının sağlıklı yaşam becerileri geliştirme (\%33.33), akademik performans belirleme (\%26.54), program geliştirme (\%19.14), rehber materyal geliştirme (\%11.11) ve sosyal ve bireysel beceriler geliştirme (\%9.88) amaçlı 
gerçekleştirildiği görülmektedir. Yapılan çalışmaların özellikle sağlıklı yaşam becerileri geliştirme, akademik performans belirleme ve program geliştirme amaçlı gerçekleştiği tespit edilmiştir. Sağlıklı yaşam becerileri geliştirme amaçlı gerçekleşen çalışmaların sebze / meyve tercihi ve tüketimi (\%15.43) ile birlikte, sağlıklı beslenme (\%11.11) ve iyileştirme bahçeleri adı altında rehabilitasyon (\%6.79) amaçlı gerçekleşmektedir. Akademik performansı belirleme amaçlı gerçekleşen çalışmaların ise özellikle fen bilimleri (\%14.81), ekoloji (\%9.88), matematik (\%7.41) ve edebi sanatlar (\%6.79) alanında yoğunlaştığı tespit edilmiştir. Program geliştirme kapsamında gerçekleşen çalışmaların \%8.64'ünde mevcut müfredata bağlı entegre programların oluşturulduğu görülürken, \%4.32'sinde bağımsız programların oluşturulduğu ve bu programların etkililiklerinin değerlendirildiği (\%9.88) çalışmalar olduğu tespit edilmiştir. Okul bahçesi uygulamalarının az da olsa rehber materyal geliştirme ve sosyal ve bireysel becerileri geliştirme amaçlı kullanıldı̆̆ı da görülmektedir. Rehber materyal geliştirme kapsamında gerçekleştirilen çalışmaların etkinlik geliştirme (\%4.32), geliştirilen etkinliğin etkisini ölçme (\%6.12) ve ölçek, test, rubrik, kontrol listesi gibi değerlendirme tekniklerinin geliştirilmesi (\%1.85) amacıyla gerçekleştirildiği tespit edilmiştir. Sosyal ve bireysel becerilerin geliştirilmesi kapsamında gerçekleştirilen çalışmaların ise problem çözme, özgüven, sorumluluk, motivasyon ve girişimcilik temelli bireysel beceriler (\%8.02) ile empati, kişilerarası ilişki (iletişim), katılım ve takım çalışması temelli sosyal beceriler (\%9.88) üzerine odaklandığı görülmektedir.

Bahçe temelli öğrenme yaklaşımı kapsamında gerçekleştirilen okul bahçesi uygulamalarında kullanılan amaçların yıllara göre dağılımı Şekil 1'de sunulmaktadır. 


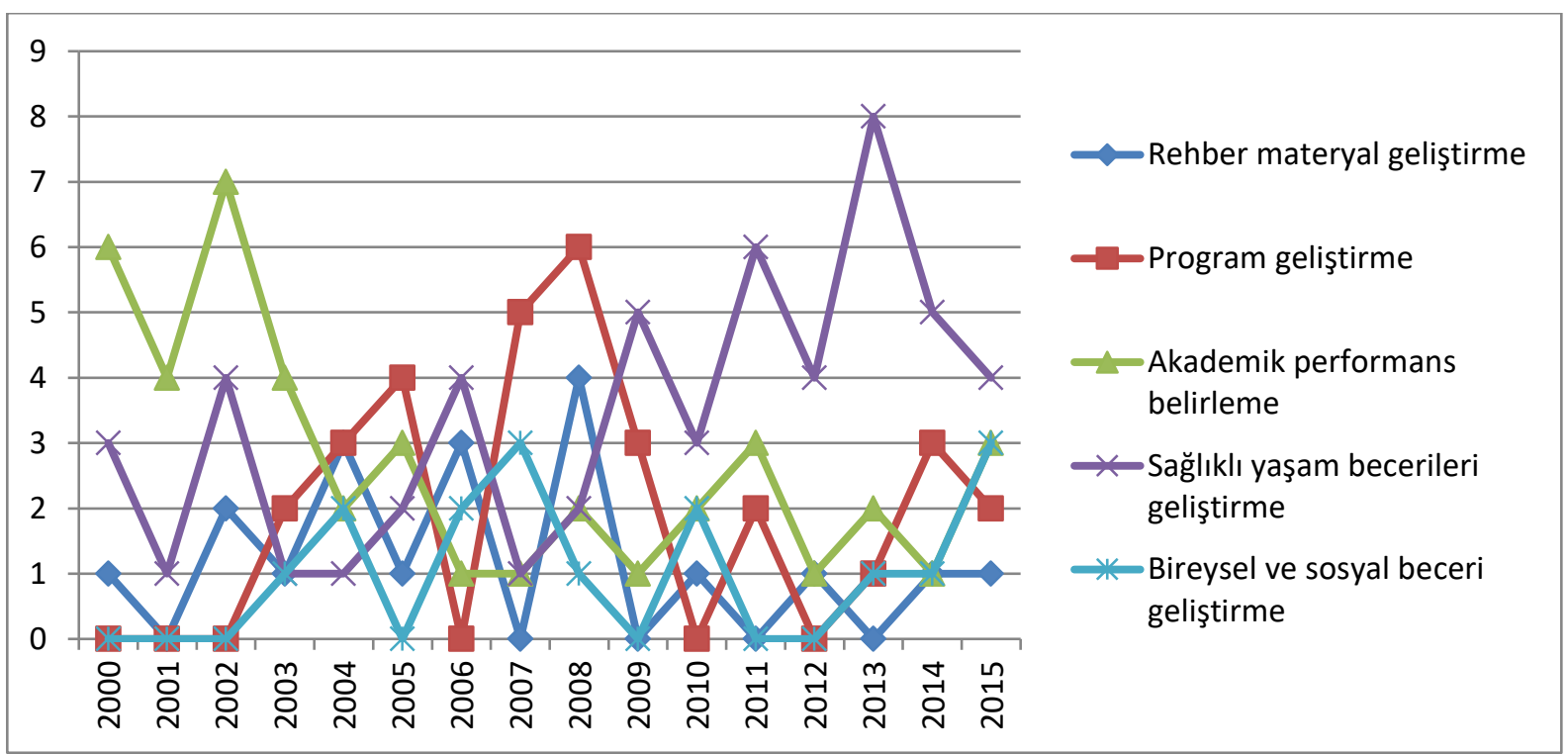

Şekil 1. Okul bahçesi uygulamalarında kullanılan amaçların yıllara göre dağglımı

Şekil 1 incelendiğinde, okul bahçesi uygulamasına yönelik yapılan çalışmalarda özellikle rehber materyal geliştirme amaçlı çalışmaların hız kazandığı görülmektedir. Rehber materyal geliştirme çalışmaları ile birlikte zaman içerisinde program geliştirme çalışmalarına da hız verildiği tespit edilmiştir. Ayrıca yapılan çalışmalarda akademik performansı belirlemeye yönelik yapılan çalışmaların azaldığı görülürken, bireysel ve sosyal becerilerle birlikte sağlıklı yaşam becerileri geliştirmeye yönelik çalışmaların artış gösterdiği görülmektedir.

Bahçe temelli öğrenme yaklaşımı kapsamında kullanılan okul bahçesi uygulamaları “araştırma modeli” başlığı altında incelendiğinde Tablo 2'de sunulan bulgulara ulaşılmıştır.

Tablo 2. Okul Bahçesi Uygulamaları Kapsamında Gerçekleştirilen Çalışmaların Araştırma Modelleri

\begin{tabular}{|c|c|c|c|}
\hline \multirow{2}{*}{ Temalar } & \multirow{2}{*}{ Kodlar } & \multicolumn{2}{|c|}{$\mathrm{n}=162$} \\
\hline & & $\mathbf{f}$ & $\%$ \\
\hline \multirow{2}{*}{$\begin{array}{l}\text { Betimsel } \\
(\mathrm{n}=28, \% 17.28)\end{array}$} & Alan Taramas1 & 22 & 13.58 \\
\hline & Karşı1laştırmalı & 6 & 3.70 \\
\hline \multirow{4}{*}{$\begin{array}{l}\text { Yorumlamac1 } \\
(\mathrm{n}=22, \% 13.58)\end{array}$} & Kültür analizi & 4 & 2.47 \\
\hline & Eylem araştırması & 7 & 4.32 \\
\hline & Özel durum & 8 & 4.94 \\
\hline & Olgu bilim & 3 & 1.85 \\
\hline \multirow{3}{*}{$\begin{array}{l}\text { Analitik } \\
(\mathrm{n}=16, \% 9.88)\end{array}$} & Derleme & 4 & 2.47 \\
\hline & Meta analiz & 9 & 5.56 \\
\hline & Tarihsel araştırmalar & 3 & 1.85 \\
\hline \multirow{2}{*}{$\begin{array}{l}\text { Deneysel } \\
(\mathrm{n}=45, \% 27.78)\end{array}$} & Yar1 deneysel & 32 & 19.75 \\
\hline & Basit deneysel & 13 & 8.02 \\
\hline
\end{tabular}




\begin{tabular}{llcc}
\hline \multirow{2}{*}{$\begin{array}{l}\text { Karma } \\
(\mathrm{n}=11, \% 6.79)\end{array}$} & Çeşitleme (nitel+nicel) & 9 & 5.56 \\
\cline { 2 - 4 } & Gömülü teori & 2 & 1.23 \\
\hline Belirtilmemiş $(\mathrm{n}=40, \% 24.69)$ & & 40 & 24.96 \\
\hline
\end{tabular}

Tablo 2 incelendiğinde, okul bahçesi uygulamalarına yönelik yapılan araştırmalarda betimsel (\%17.28), yorumlamacı (\%13.58), analitik (\%9.88), deneysel (\%27.78) ve karma (\%6.79) yöntemlerin kullanıldığı görülürmüştür. Bazı çalışmalarda ise herhangi bir araştırma modeli belirtilmeden uygulama sürecinin doğrudan açıklandığı (\%24.99) tespit edilmiştir. Yapılan çalışmalarda, özellikle deneysel ve betimsel çalışmalarla birlikte herhangi bir araştırma modeli ile sınırlandırılmadan uygulama sürecinin anlatıldığı çalışmalara rastlanmaktadır. Deneysel çalışmalarda yarı deneysel (\%19.75)ve basit deneysel (\%8.02) yöntemler kullanılırken, betimsel araştırmalard ise alan taraması modelinin (\%13.58) ve karşılaştırmalı araştırma modelinin (\%3.75) kullanıldığı tespit edilmiştir. Yorumlamacı araştırma yöntemleri altında özel durum (\%4.94), eylem araştırması (\%4.32), kültür analizi (\%2.47) ve olgu bilim (\%1.85) araştırma modelleri kullanılırken, analitik araştırma yöntemleri altında metaanaliz (\%5.56), derleme (\%2.47) ve tarihsel araştırma (\%1.85) modellerinnin kullanıldığ1 görülmektedir. Karma araştırma yöntemi başlığı altında ise nitel ve nicel araştırma modellerinin bir arada kullanıldığı çeşitleme (\%5.56) ve gömülü teori (\%1.23) modellerine rastlanmaktadir.

Bahçe temelli öğrenme yaklaşımı kapsamında kullanılan okul bahçesi uygulamalarında kullanılan araştırma modellerinin yıllara göre dağılımı Şekil 2'de sunulmaktadır.

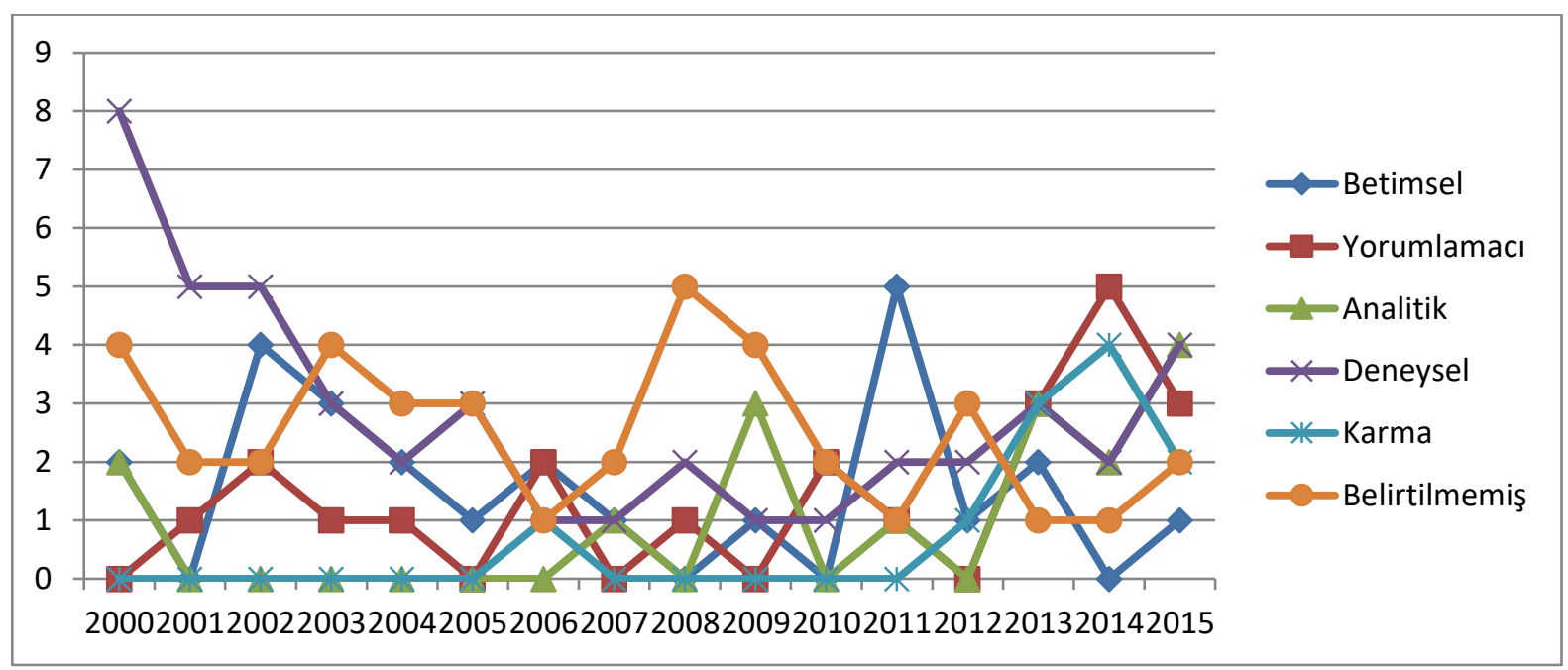

Şekil 2. Okul bahçesi uygulamalarında kullanılan araştırma modellerinin yıllara göre dağılımı 
Şekil 2 incelendiğinde, okul bahçesi uygulamasına yönelik yapılan çalışmalarda seçilen araştırma modellerinden betimsel araştırma modellerinde zaman içerisinde bir azalma meydana geldiği görülürken, yorumlamacı araştırma modellerinde bir artış olduğu görülmektedir. Analitik, deneysel ve karma yöntemlerin ise değişkenlik gösterdiği tespit edilmiştir.

Bahçe temelli öğrenme yaklaşımı kapsamında kullanılan okul bahçesi uygulamaları "araştırmanın örneklemi” başlığı altında incelendiğinde Tablo 3'te sunulan bulgulara ulaşılmıştır.

Tablo 3. Okul Bahçesi Uygulamaları Kapsamında Gerçekleştirilen Çalışmaların Örneklemleri

\begin{tabular}{|c|c|c|c|}
\hline \multirow{2}{*}{ Temalar } & \multirow{2}{*}{ Kodlar } & \multicolumn{2}{|c|}{$n=162$} \\
\hline & & f & $\%$ \\
\hline \multirow{2}{*}{ Okul Öncesi (n=35, \%21.60) } & Öğrenci & 22 & 13.58 \\
\hline & Öğretmen & 9 & 5.56 \\
\hline \multirow{4}{*}{ İlköğretim $(\mathrm{n}=76, \% 46.91)$} & Öğrenci & 52 & 32.10 \\
\hline & Öğretmen & 21 & 12.96 \\
\hline & Yönetici & 6 & 3.70 \\
\hline & Veli & 14 & 8.64 \\
\hline \multirow{2}{*}{ Ortaöğretim $(\mathrm{n}=9, \% 5.56)$} & Öğrenci & 8 & 4.94 \\
\hline & Öğretmen & 3 & 1.85 \\
\hline Üniversite $(\mathrm{n}=22, \% 13.58)$ & Öğrenci & 22 & 13.58 \\
\hline \multirow{3}{*}{$\begin{array}{l}\text { Sivil Toplum Kuruluşları } \\
(\mathrm{n}=20, \% 12.35)\end{array}$} & Öğrenci & 2 & 1.23 \\
\hline & Yetişkin & 13 & 8.02 \\
\hline & Farklı meslek grupları & 5 & 3.09 \\
\hline
\end{tabular}

Tablo 3 incelendiğinde, okul bahçesi uygulamalarının okul öncesi (\%21.60), ilköğretim (\%46.91), ortaöğretim (\%5.56), üniversite (\%13.58) ve sivil toplum kuruluşları (\%12.35) boyutunda gerçekleştirildiği tespit edilmiştir. Bütün bu boyutlarda özellikle öğrencilerle (\%65.43) yapılan çalışmalara yoğunlaşıldığı görülürken, öğrencilerle birlikte öğretmen (\%20.37), yönetici (\%3.70), veli (\%8.64), yetişkin (\%8.02) ve farklı meslek grupları (\%3.09) ile okul bahçesi uygulamalarının gerçekleştirildiği tespit edilmiştir.

Bahçe temelli öğrenme yaklaşımı kapsamında kullanılan okul bahçesi uygulamalarında kullanılan örneklem gruplarının yıllara göre dağılımı Şekil 3’te sunulmaktadır. 


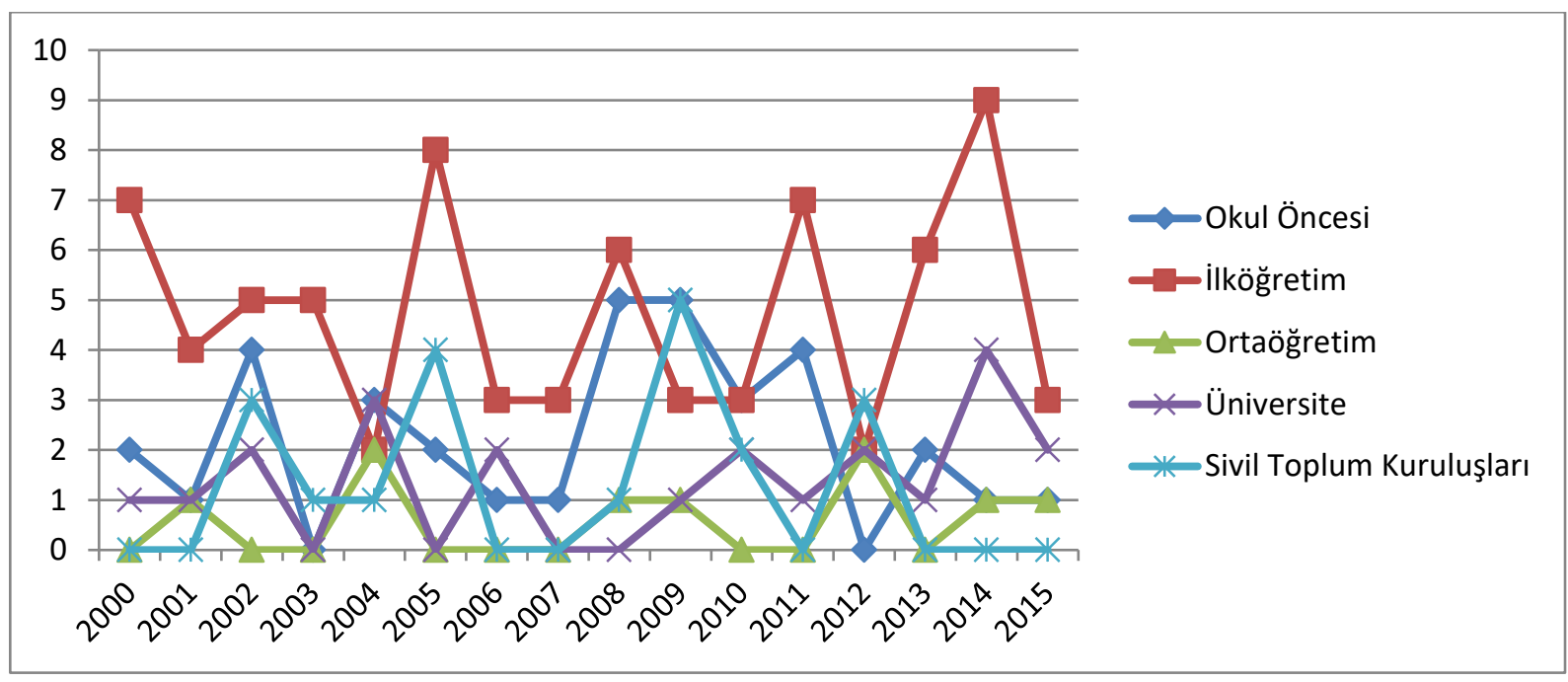

Şekil 3. Okul bahçesi uygulamalarında kullanılan örneklemlerin yıllara göre dağılımı

Şekil 3 incelendiğinde, okul bahçesi uygulamalarının kullanıldığg örneklem gruplarının tüm boyutlarda yıllara göre değişken bir durum sergilediği görülmektedir.

Bahçe temelli öğrenme yaklaşımı kapsamında kullanılan okul bahçesi uygulamaları “veri toplama araçları” başlığı altında incelendiğinde Tablo 4'te sunulan bulgulara ulaşılmıştır.

Tablo 4. Okul Bahçesi Uygulamaları Kapsamında Gerçekleştirilen Çalışmaların Veri Toplama Araçları

\begin{tabular}{lllc}
\hline \multicolumn{1}{c}{ Temalar } & \multirow{2}{*}{ Kodlar } & \multicolumn{2}{c}{$\mathbf{n = 1 6 2}$} \\
\cline { 2 - 4 } & & f & \% \\
\hline \multirow{2}{*}{$\begin{array}{l}\text { Nicel veri toplama araçları } \\
(\mathrm{n}=113, \% 69.75)\end{array}$} & Kapalı uçlu anket & 25 & 15.43 \\
\cline { 2 - 4 } & Ölçek & 37 & 22.84 \\
\cline { 2 - 4 } & Başarı testi & 58 & 35.80 \\
\hline \multirow{2}{*}{$\begin{array}{l}\text { Nitel veri toplama araçları } \\
(\mathrm{n}=71, \% 43.83)\end{array}$} & Açı uçlu anket & 16 & 9.88 \\
\cline { 2 - 4 } & Mülakat & 38 & 23.46 \\
\cline { 2 - 4 } & Gözlem & 17 & 10.49 \\
\cline { 2 - 4 } & Doküman incelemesi & 14 & 8.64 \\
\hline
\end{tabular}

Tablo 4 incelendiğinde, okul bahçesi uygulamaları kapsamında nicel (\%69.75) ve nitel (\%43.83) veri toplama araçlarının kullanıldığı görülmektedir. Nicel veri toplama araçlarından başta başarı testleri (\%35.80) olmak üzere ölçeklerin (\%22.84) ve kapalı uçlu sorulardan oluşan anketlerin (\%15.43) kullanıldığ görülmektedir. Nitel veri toplama araçlarından ise başta mülakat (\%23.46) olmak üzere gözlem (\%10.49), açık uçlu sorulardan oluşan anket (\%9.88) ve doküman incelemesinin (\%8.64) kullanıldığı tespit edilmiştir. 
Bahçe temelli öğrenme yaklaşımı kapsamında kullanılan okul bahçesi uygulamaları “sonuçlar" başlığı altında incelendiğinde Tablo 5'te sunulan bulgulara ulaşılmıştır.

Tablo 5. Okul Bahçesi Uygulamaları Kapsamında Gerçekleştirilen Çalışmaların Sonuçları

\begin{tabular}{|c|c|c|c|c|c|c|c|c|}
\hline \multirow{2}{*}{ Temalar } & \multirow{2}{*}{ Kodlar } & \multirow{2}{*}{$\mathbf{N}$} & \multicolumn{2}{|c|}{ Olumlu Etki } & \multicolumn{2}{|c|}{ Etkisiz } & \multicolumn{2}{|c|}{ Olumsuz Etki } \\
\hline & & & $\mathbf{f}$ & $\%$ & $\mathbf{f}$ & $\%$ & $\mathbf{f}$ & $\%$ \\
\hline \multirow{7}{*}{$\begin{array}{l}\text { Akademik } \\
\text { Performans }\end{array}$} & Fen bilimleri & 24 & 24 & 100 & 0 & 0 & 0 & 0 \\
\hline & Sosyal bilimler & 4 & 3 & 75 & 1 & 25 & 0 & 0 \\
\hline & Matematik & 12 & 11 & 92 & 1 & 8 & 0 & 0 \\
\hline & Görsel sanatlar & 4 & 2 & 50 & 2 & 50 & 0 & 0 \\
\hline & Edebi sanatlar (dil, vb.) & 11 & 8 & 73 & 3 & 27 & 0 & 0 \\
\hline & Ekoloji & 16 & 15 & 94 & 1 & 6 & 0 & 0 \\
\hline & Sürdürülebilir kalkınma & 5 & 5 & 100 & 0 & 0 & 0 & 0 \\
\hline \multirow{3}{*}{$\begin{array}{c}\text { Sağlıklı } \\
\text { Yaşam } \\
\text { Becerileri }\end{array}$} & Sebze / meyve tercihi ve tüketimi & 25 & 19 & 76 & 4 & 16 & 2 & 8 \\
\hline & Sağlıklı beslenme & 18 & 16 & 88 & 1 & 6 & 1 & 6 \\
\hline & Rehabilitasyon (terapi, kaygı, stres) & 11 & 7 & 64 & 3 & 27 & 1 & 9 \\
\hline \multirow{5}{*}{$\begin{array}{l}\text { Bireysel } \\
\text { Beceriler }\end{array}$} & Problem çözme & 3 & 3 & 100 & 0 & 0 & 0 & 0 \\
\hline & Özgüven & 8 & 8 & 100 & 0 & 0 & 0 & 0 \\
\hline & Sorumluluk & 6 & 6 & 100 & 0 & 0 & 0 & 0 \\
\hline & Motivasyon & 4 & 3 & 75 & 1 & 25 & 0 & 0 \\
\hline & Girişimcilik & 5 & 5 & 100 & 0 & 0 & 0 & 0 \\
\hline \multirow{4}{*}{$\begin{array}{c}\text { Sosyal } \\
\text { Beceriler }\end{array}$} & Empati & 5 & 4 & 80 & 1 & 20 & 0 & 0 \\
\hline & Kişilerarası ilişki (iletişim) & 12 & 10 & 84 & 2 & 16 & 0 & 0 \\
\hline & Katılım & 16 & 13 & 81 & 3 & 19 & 0 & 0 \\
\hline & Takım çalışması & 13 & 13 & 100 & 0 & 0 & 0 & 0 \\
\hline
\end{tabular}

Tablo 5 incelendiğinde, okul bahçesi uygulamaları kapsamında yapılan çalışmaların akademik performans, sağlıklı yaşam becerileri, bireysel beceriler ve sosyal beceriler üzerinde etkileri olduğu görülmektedir. Akademik performans kapsamında başta fen bilimleri (\%100) ve sürdürülebilir kalkınma (\%100) olmak üzere ekoloji (\%94), matematik (\%92), sosyal bilimler (\%75), edebi bilimler (\%73) ve görsel sanatlar (\%50) alanlarında olumlu etkilere sahip olduğu görülmektedir. Sağlıklı yaşam becerileri kapsamında ise sağlıklı beslenme (\%88), sebze / meyve tercihi ve tüketimi (\%76) ve rehabilitasyon (\%64) konularında daha çok olumlu etkilere sahip olduğu tespit edilmiştir. Okul bahçesi uygulamalarının bireysel becerilerden problem çözme (\%100), özgüven (\%100), sorumluluk (\%100), girişimcilik (\%100) ve motivasyon (\%75) konularında olumlu bir etkiye sahip olduğu da görülmektedir. Ayrıca sosyal becerilerden takım çalışması (\%100), iletişim (\%84), katılım (\%81) ve empati (\%80) konularında da olumlu etkiye sahip olduğu tespit edilmiştir. 


\section{Tartışma}

Okul bahçesi uygulamalarının kullanıldığı çalışmaların amacı incelendiğinde, araştırmaların başta sağlıklı yaşam becerileri geliştirme (Dyment ve Bell, 2008) ve akademik performansı belirleme (Klemmer, vd., 2005a) olmak üzere, program geliştirme (Ürey ve Çepni, 2013), rehber materyal geliştirme (Canaris, 1995) ve sosyal ve bireysel becerileri geliştirme (Ernst ve Monroe, 2004)amacıyla kullanıldığı görülmektedir. Sağlıklı yaşam becerileri bağlamında kullanılan çalışmalar incelendiğinde, çalışmaların özellikle sebze / meyve seçimi ve tüketimi amaçlı gerçekleştiği görülmektedir. Yapılan çalışmalar, budurumun son yıllarda artan hazır gıda tüketimi ve obeziteyle mücadeleden kaynaklandığınıileri sürmektedir (Ratcliffe, Merrigan, Rogers ve Goldberg, 2009; Heim, Stang ve Ireland, 2019; McAleese ve Rankin, 2011). Şekil 1 incelendiğinde de, 2000-2015 yılları arasında yapılan çalışmaların artan bir şekilde sağlıklı yaşam becerilerinin geliştirilmesi üzerine odaklandığını göstermektedir. Okul bahçesi uygulamalarında ön plana çıkan diğer bir amaç ise akademik performansın belirlenmesi ve geliştirilmesi çalışmalarıdır (Klemmer, Waliczek ve Zajicek, 2005a,b; Berezowitz, Bontrager-Yoder ve Schoeller, 2015). Özellikle okul bahçesi uygulamalarının gerçek yaşamdan örnekler sunuyor olması (Sporrow, 2008), öğrencilerin ilk elden deneyimler yoluyla yaparak ve yaşayarak öğrenmelerine imkan tanıması (Smith ve Motsenbocker, 2005), disiplinlerarası bir öğrenme ortamı sunuyor olması (Skelly ve Zajicek, 1998) ve aile katılımını desteklemesi (Bucklin-Sporer ve Pringle, 2010) nedeniyle akademik başarıyı destekliyor olması bu durumun bir sonucu olabilir. Özellikle okul bahçesi uygulamalarının anlamlı öğrenmenin gerçekleşmesinde uygun bir öğrenme ortamı sunuyor olması,okul bahçesi uygulamalarının çok boyutlu kullanımına imkan tanımakta ve bu boyutlardan biri olan ve her geçen gün önemini çok daha fazla hissettiren akademik başarının gelişimine katk1 sağlamaktadır. Okul bahçelerinin okul programlarındaki tek bir disiplin yerine birden fazla disiplin için öğrenme ortamı sunması farklı öğrenme stillerine sahip öğrencilerin genelinin yakalanabilmesi adına da önem taşımaktadır. Bu duruma bağlı olarak, okul bahçesi uygulamaları belirgin bir öğretim programı olmayan dersler için program geliştirme bağlamında kullanılabildiği gibi; fen bilimleri, matematik ve sosyal bilimler gibi bir çok disiplinin öğretim programlarında yer alan kazanımların kazandırılması için gerekli etkinliklerin materyal kaynağı olabilmektedir.

Okul bahçesi uygulamalarında kullanılan araştırma modelleri incelendiğinde, araştırmaların büyük bir çoğunluğunun belirli bir araştırma modeline sıkıştırılmadığı ve 
araştırma sürecinin açıklandığı çalışmalar olarak karşımıza çıkmaktadır (Blair, 2009). Yapılan çalışmaların süreç odaklı çalışmalar olması ve bu süreçte veri kaybuını en aza indirgemek için farklı modellerin bir arada kullanılıyor olması bu durumun bir nedeni olabilir. Belirli bir araştırma modeli altında yapılan çalışmalar incelendiğinde ise başta deneysel araştırma yöntemleri olmak üzere betimsel, yorumlamacı, analitik ve karma araştırma yöntemlerine başvurulduğu görülmektedir. Çalışmaların özellikle akademik başarı gibi etkisinin objektif bir şekilde ortaya konulması gereken durumlara odaklanmış olması deneysel çalışmaların ön plana çıkmasına neden olmuş olabilir. Ayrıca okul bahçesi uygulamaları kapsamında geliştirilen etkinliklerin ve programların etkisinin değerlendirilme ihtiyacının olması da deneysel yöntemi ön plana çıkarmaktadır. Bununla birlikte, sonuçtan çok sürece odaklanılması ve bu kapsamda sağlıklı yaşam becerileri, problem çözme, özgüven, sorumluluk, motivasyon ve girişimcilik gibi bireysel becerilerle birlikte empati, iletişim, katılım ve takım çalışması gibi sosyal becerilerin belirlenebilmesi içinse yorumlamacı ve analitik araştırma yöntemlerine ihtiyaç duyulduğu görülmektedir. Araştırma modellerindeki bu çeşitliliğin, okul bahçesi uygulamalarının hem sonuç hem de süreç odaklı çok yönlü özelliğinden kaynaklanıyor olabilir. Özellikle bu alanda yapılan çalışmaların karma araştırma modeline geçmiş olması da bu durumun bir sonucu olarak ifade edilebilir.

Son yıllarda yapılan çalışmaların örneklem grupları incelendiğinde ise doğrusal bir durumun olmadığı ve örneklem gruplarının yıllara göre değişkenlik gösterdiği görülmektedir. Okul bahçesi uygulamaları kapsamında gerçekleştirilen çalışmaların başta ilköğretim düzeyi (Dirks ve Orvis, 2005; Bakırc1, Artun ve Deniz, 2018) olmak üzere sırasıyla okul öncesi (Graue, 2001), üniversite ve ortaöğretim (Akinyemi, vd., 2008) düzeyine yoğunlaştığ1 görülmektedir. Bu merkezlerde özellikle öğrencilerin örneklem grubu olarak belirlendiği tespit edilmiştir. Okul bahçesi uygulamalarının özellikle akademik performans açısından alternatif bir öğrenme ortamı sunuyor olması örneklem olarak öğrencilerin tercih edilmesine sebep olmuş olabilir. Özellikle okul öncesi ve ilköğretim düzeyinde bu çalışmalara ağırlık verilmiş olması ise küçük yaşlarda sağlıklı beslenme alışkanlığının kazandırılmasının hedeflenmesinden ya da sosyal ve bireysel beceri kazanımı için en uygun yaş dönemleri olmasından kaynaklanıyor olabilir. Kişilik ve bir takım üst düzey becerilerin gelişimi için bu dönemin en aktif dönem olduğu düşünülürse, okul bahçesi uygulamaları aracılığıyla öğrencilerin her geçen gün yeni bir şeyleri keşfetmesi ve keşfettikleri karşısında bir takım tutum ve beceriler geliştirmesi beklenebilir (Thrive, 2006). Okul bahçesi uygulamaları konusunda öğrenci ile birlikte 
öğretmenlerle yapılan çalışmalara da rastlamak mümkündür. Özellikle etkinlik ve program geliştirme bağlamında kullanılan okul bahçesi uygulamaları için öğretmenlerin görüşlerinin alındığ1 ve öğretmenlerle birlikte değerlendirme etkinliklerinin (rubrik, kontrol listesi, gözlem formu, test, ölçek, vb.) geliştirildiği çalışmalarda örneklem olarak öğretmenlerin ön plana çıktığı görülmektedir (Mayer-Smith, Bartosh ve Peterat, 2007; Ürey, Göksu ve Karaçöp, 2017). Ayrıca okul bahçesi uygulamalarının belirli bir organizasyon çerçevesinde gerçekleştirilebilecek olması öğretmenlerin de bir takım becerilerinin (organizasyon, sınıf yönetimi, iletişim, vb.) değerlendirilmesinin önünü açmaktadır.Bahçe temelli öğrenme yaklaşımı bağlamında sivil toplum örgütlerinin de yaptıkları çalışmalara rastlamak mümkündür (Hazzard ve ark.,2011). Özellikle Kanada, Amerika ve Avustralya gibi çok kültürlü toplumlarda kültürel entegrasyon ve dil gelişiminin sağlanması ve farklı meslek grupları arasında iletişimin güçlendirilmesi adına bahçe temelli öğrenme yaklaşımının kullanıldığı görülmektedir (Cutter-Mackenzie, 2009; Tangen ve Fielding-Barnsley, 2007).

Okul bahçesi uygulaması kapsamında kullanılan veri toplama araçları incelendiğinde araştırmanın amacı ve araştırma modeline paralel olarak nicel ve nitel veri toplama araçlarına başvurulduğu görülmektedir. Nicel veri toplama araçları olarak başta başarı testleri olmak üzere, tutum ölçekleri ve kapalı uçlu ve seçenekli sorulardan oluşan anketlerin kullanıldığ görülürken, nitel veri toplama araçlarından başta mülakat olmak üzere gözlem, doküman incelemesi ve açık uçlu sorulardan oluşan anketlerin kullanıldığg tespit edilmiştir. Bu durumun tamamıyla araştırmanın amacı ve araştırma modeline bağlı olarak gelişen bir durum olduğu düşünülmekte olup, okul bahçesi uygulamalarının süreç ve sonuç odaklı çalışmalar olması hem nicel hem de nitel veri toplama araçlarının tercih edilmesine neden olmaktadır. $\mathrm{Bu}$ durumun çalışma sürecindeki veri kaybını da en aza indirgeyeceği düşünülmektedir.

Yapılan çalışmaların sonuçları incelendiğinde ise okul bahçesi uygulamalarının büyük çoğunlukta olumlu etkiye sahip olduğu tespit edilmiştir. Okul bahçesi uygulamalarının gerçekleştirilme amacı olan gerek akademik performansın gelişiminde, gerek sağlıklı yaşam becerilerinin gelişiminde, gerekse sosyal ve bireysel becerilerin gelişiminde olumlu bir etkiye sahip olduğu görülmektedir. Akademik performans açısından özellikle fen bilimleri, ekoloji ve matematik üzerindeki etkisinin diğer disiplin alanlarına göre oldukça fazla olduğu görülmektedir (Sparrow, 2008; Ürey ve Çepni, 2015; Byrd, Haque, Tai, McLellan ve Knight, 2007). Okul bahçesi uygulamalarının konu içeriğinin merkezinde fen bilimleri ve ekoloji bilgisinin merkezde yer alıyor olması bu durumun bir sonucu olabilir (Ürey ve ark., 2013). 
Özellikle fen bilimleri açısından okul bahçesi uygulamaları aracılığıyla öğrenciler edilgen durumdan kurtarılarak etkin öğrenme süreçlerine dahil olabilir ve gerçek yaşamla bütünleşerek soyut fen kavramları üzerinde kalıcı öğrenmeyi gerçekleştirebilirler. Ayrıca son yıllarda ön plana çıkan sürdürülebilir kalkınma açısından bir merkez olarak ele alınması ve elde edilen sonuçların \%100 oranında olumlu etki gösteriyor olması küçük yaşlarda çevre bilinci ve çevresel farkındalığın kazandırılması adına da önem arz etmektedir. Okul bahçesi uygulamaları öncesinde öğrenciler çevre kavramını bir nesne veya yer olarak algılarken, uygulamalar sonrasında bitki, hayvan, çiçek, toprak ve hava ile olan deneyimlerine farklı manalar yükler ve bunlar arasındaki dinamik döngüyü keşfeder. Böylece doğadaki döngüsel süreci fark ederek sürdürülebilirlik bir çevre için doğada var olan canlı ve cansız tüm unsurlara ihtiyacı olduğunu fark eder (Wells, 2000; Mayer-Smith ve ark., 2007). Sağlıklı yaşam becerileri açısından incelendiğinde ise sebze / meyve tercihi ve tüketimi ile birlikte sağlıklı beslenmenin kazandırılması konusunda okul bahçesi uygulamalarının olumlu bir etkiye sahip olduğu görülmektedir. Bu kapsamda yapılan çalışmalarda özellikle hazır gıdalar ve obezite sorunu ön plana çıkarılmakta olup bu sorunların önüne geçilmesi noktasında okul bahçesi uygulamalarının kullanılması gerektiği ileri sürülmektedir (Ozer, 2007). Dahlgren (2003) bugünün çocuklarının bir önceki nesile göre daha az doğal çevre ile iletişim kurduğunu ve çevresinde olup bitenlerden habersiz olduğunu ifade etmektedir. Bu durumun çocuklarda duygusal çöküntüye ve beraberinde fiziksel aktivitelerin azalmasına neden olarak obezite sorununun oluşmasına neden olduğu ileri sürülmektedir (Dyment ve Bell, 2008; Hazzard ve ark., 2011). Okul bahçesi uygulamaları aracılığıyla taze meyve ve sebze tercihi ve tüketiminin özendirilerek çocuklarda sağlıklı beslenmenin alışkanlık haline getirilmesi sağlanabilir. Ayrıca iyileştirme bahçeleri altında peyzaj mimarlığının çalışma sahasına giren bahçe temelli öğrenme yaklaşımı bireylerin kaygı ve stres düzeylerini azaltacak bir terapi merkezi olarak da işlev görmektedir (Pouya, Cındık Akıncı ve Demirel, 2006). Yapılan çalışmalar, çocukların zamanlarının çoğunu kapalı mekanlarda elektronik aletlerle geçirmesinin bir çok fiziksel ve psikolojik rahatsızlığa (obezite, biofobia, hiperaktivite, kaygı bozuklukları, depresyon, şiddet eğilimleri, uyum sorunları, vb.) neden olduğunu ileri sürmektedir (Louv, 2008; Taylor, Kuo ve Sullivan, 2001; Wells, 2000). Wells (2000) okul bahçesi uygulamaları aracılığıyla doğa ile etkileşime geçen çocuklarınyaşadıkları bu travmatik olaylara karşı psikolojik koruma sağlayabileceği ve daha az bu sorunlarla karşılaşabileceklerini ifade etmektedir. Tüm bunların yanı sıra elde edilen bulgular, okul bahçesi uygulamalarının sosyal ve bireysel becerilerin 
gelişimi kapsamında da olumlu bir etkiye sahip olduğunu göstermektedir. Yapılan çalışmalar, okul bahçesi uygulamaları aracılığıyla öğrencilerin güvenli ve yaratıcı oyunlara imkan bulduğunu (Malone ve Tranter, 2003; Moore, 1996), bu imkana bağlı olarak sosyal ilişkilerini artırdığını (Dyment ve Bell, 2008), sorumluluk, özgüven ve problem çözme gibi bireysel becerilerini geliştirdiğini (Bartosh, Tudor, Ferguson ve Taylor, 2006; Skelly ve Bradley, 2007) ve öğrencilerle birlikte öğretmenlere zengin öğrenme ortamları sunarak motivasyonlarını artırdığını (Dyment, 2005) ifade etmektedir.

\section{Sonuçlar}

1. Bahçe temelli öğrenme yaklaşımı kapsamında kullanılan okul bahçesi uygulamaları sağlıklı yaşam becerileri geliştirme, akademik performansı belirleme ve geliştirme, program geliştirme, rehber materyal geliştirme ve sosyal ve bireysel beceriler geliştirme amacıyla gerçekleştirilmektedir. Akademik performansı belirleme ve geliştirme amaçlı çalışmaların sayısı son yıllarda azalırken, sağlıklı beslenme becerilerini geliştirilmesi üzerine yapılan çalışmalarda artış göstermektedir.

2. Bahçe temelli öğrenme yaklaşımı kapsamında kullanılan okul bahçesi uygulamalarındadaha çok herhangi bir araştırma modeli kullanılmadan araştırma süreci açıklanırken; araştırma modeli kullanılan çalışmalarda başta deneysel model olmak üzere betimsel, yorumlamacı, analitik ve karma araştırma modellerine yer verilmektedir. Son yıllarda deneysel çalışmalarda azalma görülürken, karma araştırma modeli ile yapılan çalışmalarda bir artış göstermektedir.

3. Bahçe temelli öğrenme yaklaşımı kapsamında kullanılan okul bahçesi uygulamaları özellikle küçük yaşlarda sağlıklı beslenme alışkanlığı ile birlikte sosyal ve bireysel becerilerin gelişebileceği noktasından hareketle okul öncesi ve ilköğretim dönemine yoğunlaşmıştır. Okul bahçesi uygulamalarının okul ortamlarında alternatif bir öğrenme ortamı oluşturması nedeniyle daha çok öğrencilerle birlikte gerçekleştirilen çalışmalardır.

4. Bahçe temelli öğrenme yaklaşımı kapsamında kullanılan okul bahçesi uygulamalarının hem süreç hem de sonuç odaklı çalışmalar olması sebebiyle hem nicel hem de nitel veri toplama araçlarına başvurulmaktadır.

5. Bahçe temelli öğrenme yaklaşımı kapsamında kullanılan okul bahçesi uygulamaları akademik performansın belirlenmesi ve geliştirilmesi, sağlıklı yaşam becerilerinin geliştirilmesi ve bireysel ve sosyal becerilerin geliştirilmesi konularında olumlu bir etkiye 
sahiptir. Akademik performansın geliştirilmesi konusunda daha çok fen bilimleri ve ekoloji ön plana çıkarken, sağlıklı yaşam becerilerini gelişimi noktasında sağlıklı meyve / sebze tercihi ve tüketimi ön plana çıkmaktadır. Ayrıca okul bahçesi uygulamaları aracılığıyla problem çözme, özgüven, sorumluluk, motivasyon ve girişimcilik gibi bireysel değer ve becerilerin gelişimi sağlanabilirken, empati, iletişim, katılım ve takım çalışması gibi sosyal becerilerinde gelişimi sağlanabilmektedir.

\section{Makalenin Bilimdeki Konumu (Yeri)}

Matematik ve Fen Bilimleri Eğitimi Bölümü / Fen Bilgisi Eğitimi

\section{Makalenin Bilimdeki Özgünlüğü}

Çıktıları açısından oldukça geniş bir yelpazeye sahip olan bahçe temelli öğrenme yaklaşımı ve bu yaklaşımın temel alındığı okul bahçesi uygulamaları her geçen gün eğitimöğretim programları üzerindeki etkisini biraz daha artırmaktadır. Özellikle ülkemiz açısından ilkokulda serbest etkinlik çalışmaları ve ortaokulda bilim uygulamaları dersleri ile örtüşebileceği düşünülen bu uygulamaların geçmişten günümüze yansımaları ve son yıllardaki eğilimleri bu tür çalışmaları uygulayacak olan öğretmenlere 1şık tutacaktır. Bu durum, bahçe temelli öğrenme yaklaşımı kapsamında yayınlanan bilimsel makalelerin pek çok ölçüt açısından incelenmesini gerekli kılmaktadır. Bu bağlamda, yapılan çalışma ile okul bahçesi uygulamalarının içerik analizini yaparak, bahçe temelli öğrenme yaklaşımına yönelik eğilimlerin ortaya konması amaçlanmaktadır.

\section{Kaynaklar}

Akinyemi, O. M., Fragstein, P., Agnew, D. (2008). The state of school gardening programs in sustainable development in Nigeria: Obstacles and opportunities. The International Journal of Learning, 15(10), 231-245.

Aydın, A., Bakırcı, H. ve Ürey, M. (2012). Serbest etkinlik çalışmaları dersine yönelik sınıf öğretmen görüşleri. Milli Eğitim Dergisi, 41(193), 214-231.

Bakırcı, H., Artun, H. ve Deniz, A. N. (2018). Ortaokul altıncı sınıf öğrencilerinin hobi bahçesi hakkında görüşleri. Papers Presented at the AGP Humanities and Social Sciences Conference, 4-6 Mayıs 2018, Prag, Çek Cumhuriyeti. 
Balkan-Kıyıc1, F., Atabek-Yiğit, E. (2010). Science education beyond the classroom: A field trip to wind power plant. International Online Journal of Educational Sciences, 2(1), 225-243.

Bartosh, O., Tudor, M., Ferguson, L., Taylor, C. (2006). Improving test scores through environmental education: Is it possible? Applied Environmental Education and Communication, 5(3), 161-169.

Berezowitz, C. K., Bontrager-Yoder, A. B., Schoeller, D. A. (2015). School gardens enhance academic performance and dietary outcomes in children, Journal of School Health, 85, 508-518.

Blair, D. (2009). The child in the garden: An evaluative review of the benefits of school gardening. Journal of Environmental Education, 40(2), 15-38.

Brynjegard, S. (2001). School gardens: Raising environmental awareness in children. (Reproductions supplied by EDRS), Dominican University of California, USA.

Bucklin-Sporer, A., Pringle, R. K. (2010). How to grow a school garden: A comlete guide for parents and teachers, Portland: Timber Press.

Bundschu-Mooney, E. (2003). School garden investigation: Environmental awareness and education, (Reproductions supplied by EDRS), Dominican University of California, USA.

Byrd, R. K., Haque, M. T., Tai, L., McLellan, G. K., Knight, E. J. (2007). Designing a children's water garden as an outdoor learning lab for environmental education. Applied Environmental Education and Communication, 6, 39-47.

Canaris, I. (1995). Growing foods for growing minds: Integrating gardening and nutrition education into the total curriculum. Children's Environments, 12(2), 264-70.

Cutter-Mackenzie, A. (2009). Multicultural school gardens: Creating engaging garden spaces in learning about language, culture and environment. Canadian Journal of Environmental Education, 14, 122-135.

Çalık, M., Sözbilir, M. (2014). İçerik analizinin parametreleri, Eğitim ve Bilim, 39(174), 3338.

Çepni, S. (2010). Araştırma ve proje çalışmalarına giriş (5. Baskı), Trabzon: Celepler Matbaacilik. 
Çepni, S., Aydın, M., Haşıloğlu, M. A., Ürey, M. (2012). The first steps on agricultural education in Turkish elementary schools: The school garden project. Energy Education Science and Technology Part B:Social and Educational Studies, 4(3), 1589-1602.

Dahlgren, A. (2003). Lecturer finds urban sprawl linked with obesity, Sweden: The Daily Free Press.

Damon, B. (2001). Model projects: DaVinci water garden. Keepers of the waters. http://www.wellnessgoods.com/davinci adresinden 4.11.2008 tarihinde edinilmiştir.

DeMarco, L. W., Relf, D., McDaniel, A. (1999). Integrating gardening into the elementary school curriculum. HortTechnology, 9, 276-281.

Dirks, A. E., Orvis, K. (2005). An evolution of the junior master gardener program in third grade classrooms. HortTechnology, 15, 443-447.

Dyment, J. E. (2005). Green school grounds as sites for outdoor learning: Barriers and opportunities. International Research in Geographical and Environmental Education 14(1), 24-41.

Dyment, J. E., Bell, A. C. (2008). Grounds for health: The intersection of green school grounds and health-promoting schools. Environmental Education Research, 14(1), 77-90.

Ernst, J., Monroe, M. (2004). The effects of environment-based education on students' critical thinking skills and disposition toward critical thinking. Environmental Education Research,10(4), 507-22.

Graue, E. (2001). What's going on in the children's garden? Kindergarten today, Young Children, 56(3), 67-73.

Harlen, W., Simon, S. (2001). Elementary school science and the rise and rise ofprimary science. School Science Review, 82(300), 49-57.

Hazzard, E. L., Moreno, E., Beall, D.B., Zidenberg-Cherr, S. (2011). Best practices models for 1mplementing, sustaining, and using instructional school gardens in California. Journal of Nutrition Education and Behavior, 43(5), 409-413.

Heim, S., Stang, J., Ireland, M. (2009). A garden pilot Project enhances fruit and vegetable consumption among children, Journal of American Dietetic Association, 109(7), 12201226.

Kane, L. (2004). Educators, learners, and active learning methodologies. International Journal of Lifelong Education, 23(3), 275-286. 
Klemmer, C. D., Waliczek, T. M., Zajicek, J. M. (2005a). Development of a science achievement evaluation instrument for a school garden program. HortTechnology, 15(3), 433-438.

Klemmer, C. D., Waliczek, T. M., Zajicek, J. M. (2005b). Growing minds: The effect of a school gardening program on the science achievement of elementary students. HortTechnology, 15(3), 448-552.

Kohlstedt, S. G. (2008). "A better crop of boys and girls": The school gardening movement 1890-1920. History of Education Quarterly, 48(1), 58-93.

Laçin-Şimşek, C. (2011). Fen öğretiminde okul dışı öğrenme ortamları. C. Laçin Şimşek (Ed.). Okul dışı öğrenme ortamları ve fen eğitimi (1-23), Ankara: Pegem Yayıncılık.

Lekies, K. S., Sheavly, M. E. (2007). Fostering children's 1nterests in gardening. Applied Environmental Education and Communication, 6, 67-75.

Lieberman, G.A. and Hoody, L. L. (1998). Closing the achievement gap: Using the environment as an integrated context for learning. San Diego, CA: State Education and Environment Roundtable.

Louv, R. (2008). Last child in the woods: Saving our children from nature-deficit disorder. Chapel Hill, North Carolina: AlgonquinBooks.

Lownds, N. (2000). Millennium focus children's gardening: Growing the next generation. The American Gardener, 19-24.

Malone, K., Tranter, P. J. (2003). School grounds as sites for learning: Making the most of environmental opportunities. Environmental Education Research, 9(3), 283-303.

Maloof, J. (2006). Experience this: The experiental approach to teaching environmental issues. Applied Environmental Education and Communication, 5(3), 193-197.

Mayer-Smith, J., Bartosh, O., Peterat, L. (2007). Teaming children and elders to grow food and environmental consciousness, Applied Environmental Education and Communication, 6(1), 77-85.

McAleese, J. D., Rankin, L. L. (2007). Garden based nutrition education affects fruit and vegetable consumption in sixth grade adolescents. American Dietetic Association, 107, 662-665.

Miller, M. A. (2005). An exploration of children's gardens: Reported benefits, recommended elements, and preferred visitor autonomy. Unpublished doctoral dissertation, The Ohio State University, Columbus, $\mathrm{OH}$. 
Moore, R.C. (1996). Outdoor settings for playing and learning: Designing school grounds to meet the needs of the whole child and whole curriculum. North American Montessori Teacher's Association Journal, 21(3), 97-120.

Ozer, E.(2007). The effects of school gardens on students and schools: conceptualization and considerations for maximizing healthy development. Health Education \& Behavior, 34(6), 846-863.

Rahm, J. (2002). Emergent learning opportunities in an inner-city youth gardening program. Journal of Research in ScienceTeaching, 39, 164-184.

Ratcliffe, M. M., Merrigan, K. A., Rogers, B. L., Goldberg, J. P. (2009). The effects of school garden experiences on middle school-aged students' knowledge, attitudes and behaviors associated with vegetable consumption, Health Promotion Practice January, 12(1), 3643.

Shair, G. (1999). A history of children's gardens, The Public Garden, 99(14), 9-11.

Skelly, S. M., Bradley, J. C. (2007). The growing phenomenon of school gardens: Measuring their variation and their affect on students' sense of responsibility and attitudes toward science and the environment. Applied Environmental Education and Communication, 6, 97-104.

Skelly, S. M., Zajicek, J. M. (1998). Theeffect of an interdisciplinary garden program in the environmental attitudes of elementary school students. Hortechnology, 8(4),579-583.

Smith, L. L., Motsenbocker, C. E. (2005). Impact of hands-on science through school gardening in Louisiana publicelementary schools. HortTechnology, 15, 439-443.

Sparrow, L. (2008). Real and relevant mathematics: Is it realistic in the clasroom? Australian Primary Mathematics Classroom, 13(2), 4-8.

Tangen, D., Fielding-Barnsley, R. (2007). Environmental education in a culturally diverse school. Australian Journal of Environmental Education, 23, 23-30.

Taylor, A. F., Kuo, F., Sullivan, W. C. (2001). Coping with add: The surprising connection to green play setting. Environment and Behavior, 33(1), 54-77.

Thrive, (2006). Learning under the sky: The benefits of gardening for children with special educational needs, http://www.thrive.org adresinden 10.10.2010 tarihinde edinilmiştir.

Ürey, M., Çepni, S. (2014a). Fen temelli ve Disiplinlerarası okul bahçesi programının öğrencilerin fen ve teknoloji dersine yönelik tutumları üzerine etkisinin farklı değişkenler 
açısından değerlendirilmesi, Ondokuz Mayls Üniversitesi Eğitim Fakültesi Dergisi, $33(2), 537-548$.

Ürey, M., Çepni, S. (2014b). Serbest etkinlik çalışmaları dersine yönelik bir program önerisi: Okul bahçesi programı, Milli Eğitim Dergisi, 202, 37-58.

Ürey, M. (2013). Serbest etkinlik çalışmaları dersine yönelik fen temelli ve disiplinlerarası okul bahçesi programının geliştirilmesi ve değerlendirilmesi, Yayınlanmamış doktora tezi, Karadeniz Teknik Üniversitesi, Trabzon.

Ürey, M., Çepni, S. (2015). Fen temelli ve disiplinlerarası okul bahçesi programının bazı fen ve teknoloji dersi kazanımları üzerine etkisinin farklı değişkenler açısından değerlendirilmesi. Hacettepe Üniversitesi Eğitim Fakültesi Dergisi, 30(2), 166-184.

Ürey, M., Çepni, S., Kaymakçı, S. (2015). Fen temelli ve disiplinlerarası okul bahçesi programının bazı sosyal bilgiler öğretim programı kazanımları üzerine etkisinin değerlendirilmesi. Uludağ Üniversitesi Eğitim Fakültesi Dergisi, 28(1), 7-29.

Ürey, M., Çepni, S., Köğce, D., Yıldız, C. (2013). Serbest etkinlik çalışmaları dersi kapsamında geliştirilen fen temelli ve disiplinlerarası okul bahçesi programının öğrencilerin bazı matematik kazanımları üzerine etkisinin değerlendirilmesi. Türk Fen Eğitimi Dergisi,10(3), 37-58.

Ürey, M., Göksu, V., Karaçöp, A. (2017). Teachers' views about school garden program developed for free activities course, Elementary Education Online, 16(1), 1-14.

Waliczek, T. M., Logan, P., Zajicek, J. M. (2003). Exploring the impact of outdoor environmental activities on children using a qualitative text data analysis system, HortTechnology, 13, 684-688.

Wells, N. (2000). At home with nature: Effects of 'greenness' on children's cognitive functioning. Environment and Behavior, 32(6), 775-795.

\section{Summary}

\section{Problem Statement}

In the context of a garden-based learning approach, the centers used as school or out door learning environments are zoo gardens, botanical gardens and school gardens (Laçin Şimşek, 2011; Ürey, 2013). While zoos are park areas for the exhibition of wild and domestic animals; botanical gardens are natural living and learning areas that are arranged to reflect the kinship relationships between plant groups (Balkan K1yıc1, 2010). School gardens are 
described as; "planned and programmed garden farming activities which is based on gardenbased learning and which students formed designing by themselves, in which various products are grown located in school ground (Miller, 2005, p.49)”. As part of the school garden practices, it is known that animal breeding has been done together with plant growing. It is also possible to come across school garden practices such as bird watching through bird watching houses, silkworm breeding and poultry farming are carried out (Ürey, 2013).

The garden-based learning approach, which has a wide range of outputs, and the school garden practices on which this approach is based, are increasing the effect on the curriculum day by day. Especially in terms of our country, these activities, which are thought to be compatible with free activity studies in primary school and overlap with lessons in science applications in secondary school, will shed light on the past and present tendencies and trends in recent years to teachers who will apply such studies. This necessitates the examination of scientific articles published within the framework of the garden-based learning approach in terms of many criteria. In this context, the aim of the study is to analyze the contents of school garden practices and to reveal the trends towards garden-based learning approach. Within the scope of this aim, the objectives of the school garden practices, research models, samples, data collection tools and results of the research conducted between 2000 and 2015 were examined and the changes in these dimensions were tried to be investigated by years.

\section{Purpose of the Study}

The aim of the study is to analyze the content of school garden practices and to identify trends for a garden-based learning approach.

\section{Method}

In the study conducted, document analysis is used from the analytical research methods. The document analysis is a process of collecting the existing records and documents related to the work to be done and encoding them according to a certain norm or system. The main purpose of the document analysis is to be able to reveal general trends and alternative thoughts and ideas by going out of the way of the many structures that reach new knowledge or discovery (Çepni, 2010).

In the research conducted, a total of 162 scientific articles published as full paper in 21 different journals were reached. 154 of them were published internationally and 8 of them nationally. The articles reached are the scientific articles published in the related field between the years 2000-2015. These articles were taken from databases such as Web of Science, ERIC, 
Academic Search Complete, Google Scholar, Agriculture Journals and ULAKBIM. In the analysis of the obtained articles, "School Garden Practices Survey Form (SGPSF)" developed by the researcher was used (Appendix-1). The data on SGPSF were analyzed by scoring method. Content of the article were presented under the title of purpose, research model, sample, data collection tools and results. The obtained findings were visualized with the help of frequency and percentage tables and graphs.

\section{Finding and Discussion}

According to the results of the analysis, it is aimed to develop healthy living skills with the determination (Dyment \& Bell, 2008) and development of academic performance (Klemmer, et al, 2005a; Klemmer, et al, 2005a; Ürey \& Çepni, 2015); in studies conducted within the scope of school garden practices. When the research models used in the researches are examined, it is seen that a specific research model is not used and the experimental research model is preferred. It has been determined that quantitative and qualitative data collection tools are used in the sample, especiallypre-primary and primary school students are included (Graue, 2001; Dirks \& Orvis, 2005). When the results of school gardening practices are examined, it has been found that they have a positive effect on the development of academic performance, the development of healthy living skills, and the development of individual and social skills.

\section{Conclusion}

School garden practices used within the context of a garden-based learning approach have a positive impact on the identification and development of academic performance, the development of healthy life skills, and the development of individual and social skills. While scientific science and ecology are at the forefront in improving academic performance; healthy fruit / vegetable preference and consumption are at the forefront in the development of healthy life skills. In addition, the development of individual values and skills such as problem solving, self-reliance, responsibility, motivation and entrepreneurship can be achieved through school garden practices; social skills such as empathy, communication, participation and teamwork can also be provided.

EK-1: Okul Bahçesi Uygulamaları Alan Tarama Formu (OBATF) 


\begin{tabular}{|c|c|c|c|c|c|c|c|c|c|c|}
\hline Makale No & & & & & & & & & & \\
\hline $\begin{array}{l}\text { Makalenin } \\
\text { Adı }\end{array}$ & & & & & & & & & & \\
\hline $\begin{array}{l}\text { Makalenin } \\
\text { Yazar/ları }\end{array}$ & & & & & & & & & & \\
\hline Makalenin & () Ulusal & & & $A d t$ & & & Yhth & Cilt & Sayl & Savfa \\
\hline $\begin{array}{l}\text { Yayımlandğ } \\
\text { Dergi }\end{array}$ & () Uluslararasi & & & & & & & & & \\
\hline Amaç & $\begin{array}{l}\text { () etkinlik gelişti } \\
\text { () program gelişt } \\
\text { () akademik perf } \\
\text { () çavresel tutum } \\
\text { () çavre bilgisi }\end{array}$ & $\begin{array}{l}\text { me } \\
\text { ime } \\
\text { ormans }\end{array}$ & $\begin{array}{l}\text { sürdi } \\
\text { ) sağhl } \\
\text { ) birey } \\
\text { sosy } \\
\text { ) diğes }\end{array}$ & $\begin{array}{l}\text { irülebilir kall } \\
\text { kly beslenme } \\
\text { sel beceriler } \\
\text { al beceriler }\end{array}$ & Itamin & ma & $\operatorname{sxs} x$ & $\sin x \times x>x$ & . & \\
\hline & $\begin{array}{c}\text { Betimsel } \\
\text { Arastumalar }\end{array}$ & $\begin{array}{l}\text { Yorumlayt } \\
\text { Arastrumal }\end{array}$ & & $\begin{array}{r}\text { Analitik } \\
\text { Arastumal }\end{array}$ & & $\begin{array}{c}\text { Deneyse } \\
\text { Arastuma }\end{array}$ & & & ma Yaklo & \\
\hline $\begin{array}{l}\text { Arasttrma } \\
\text { Modeli }\end{array}$ & $\begin{array}{l}\text { () tarama } \\
\text { () özel durum } \\
\text { () gelişimsel } \\
\text { () karşılaştımal }\end{array}$ & $\begin{array}{l}\text { () külturr anali } \\
\text { () ozel durum } \\
\text { () eylem araşt } \\
\text { () olgu bilim }\end{array}$ & $\begin{array}{l}\text { izi } \\
\text { tirmasl }\end{array}$ & $\begin{array}{l}\text { () doküm } \\
\text { analizi } \\
\text { ( ) tarihsel } \\
\text { araştırmals }\end{array}$ & & $\begin{array}{l}\text { () tam deney } \\
\text { () yari dene } \\
\text { () basit den } \\
\text { () tek denek }\end{array}$ & $\begin{array}{l}\text { ysel } \\
\text { ysel } \\
\text { yysel } \\
\text { li }\end{array}$ & $\begin{array}{l}\text { () açikls } \\
\text { () keşfe } \\
\text { () geşitl } \\
\text { () gömü }\end{array}$ & $\begin{array}{l}\text { yicl (nice } \\
\text { yici (nitel } \\
\text { me (nite) } \\
\text { iu teori }\end{array}$ & $\begin{array}{l}\rightarrow \text { nitel) } \\
\rightarrow \text { nicel) } \\
\text { inicel) }\end{array}$ \\
\hline & Okul Oncesi & Ilkögrretion (1) & & Ortaöğret & & Universi. & & Sivil To & olum Ku & Iusglan \\
\hline Örneklem & $\begin{array}{l}\text { () ögrenci } \\
\text { () oğretmen } \\
\text { () yönetici } \\
\text { () veli }\end{array}$ & $\begin{array}{l}\text { () ögrenci } \\
\text { () oğretmen } \\
\text { () yönetici } \\
\text { () veli }\end{array}$ & & $\begin{array}{l}\text { () ögrenci } \\
\text { () ögretm } \\
\text { () yönetic } \\
\text { () veli }\end{array}$ & & $\begin{array}{l}\text { () öğrenci } \\
\text { () oggretim e. } \\
\text { () yönetici } \\
\text { () veli }\end{array}$ & leman1 & $\begin{array}{l}\text { () g̈ğen } \\
\text { () yetişl } \\
\text { () mesle } \\
\text { () diğer }\end{array}$ & $\begin{array}{l}\text { ii } \\
\text { in } \\
\text { k gruplar }\end{array}$ & 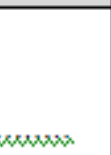 \\
\hline & Nicel & Veri Toplama Ara & aclan & & & Nitel & VeriTo & plama $A r$ & iclan & \\
\hline $\begin{array}{l}\text { Veri } \\
\text { Toplama } \\
\text { Araçları }\end{array}$ & $\begin{array}{l}\text { () kapali uçlu anl } \\
\text { () ölçek } \\
\text { () başarı testi } \\
\text { () diğer }\end{array}$ & cet & 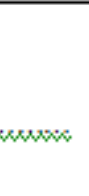 & & & $\begin{array}{l}\text { açlk uçlu anket } \\
\text { mülakat } \\
\text { gözlem } \\
\text { doküman } \\
\text { diğer }\end{array}$ & & 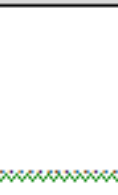 & 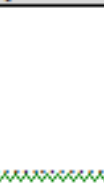 & \\
\hline & & Nicel Veri Analizi & & & & & Nitel V & eriAnaliz & & \\
\hline $\begin{array}{l}\text { Veri Analiz } \\
\text { Yöntemi }\end{array}$ & 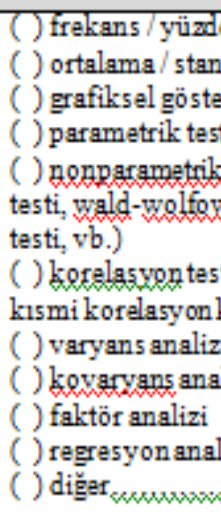 & 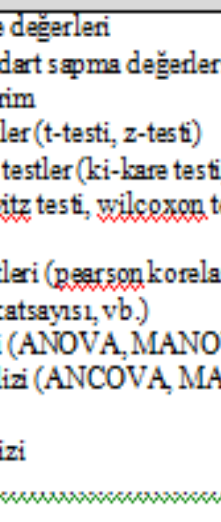 & $\begin{array}{l}\text { ri } \\
\text { ri, mann } \\
\text { testi, the } \\
\text { asyonks } \\
\text { ANA) } \\
\text { ANCOV }\end{array}$ & 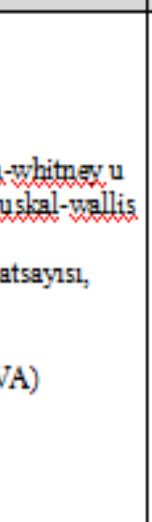 & & $\begin{array}{l}\text { içerik anal lizi } \\
\text { ) betims el analiz } \\
\text { ) diğer }\end{array}$ & 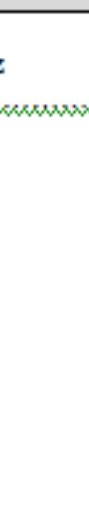 & 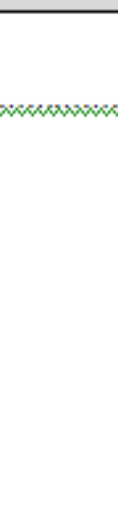 & 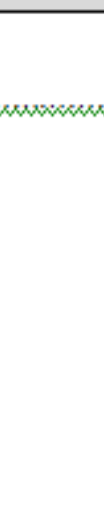 & $\operatorname{scs} x$ \\
\hline & $\begin{array}{c}\text { Etkinlik türü ve } \\
\text { etki durumu }\end{array}$ & $\begin{array}{c}\text { Program türü ve } \\
\text { etki durumu }\end{array}$ & $\begin{array}{r}\text { Ah } \\
\text { perfor } \\
\text { ve et } \\
\end{array}$ & $\begin{array}{l}\text { rademik } \\
\text { rmans türü } \\
\text { ki durumu }\end{array}$ & & $\begin{array}{l}\text { ağliki yasam } \\
\text { scerileri ve etki } \\
\text { durumu }\end{array}$ & $\begin{array}{r}\text { Birey: } \\
\text { türiu } \\
d u\end{array}$ & $\begin{array}{l}\text { el beceri } \\
\text { ve etki } \\
\text { irumu }\end{array}$ & $\begin{array}{r}\text { Sosva } \\
\text { türü } \\
d u \\
\end{array}$ & $\begin{array}{l}\text { beceri } \\
\text { e etki } \\
\text { umu }\end{array}$ \\
\hline Sonuc & 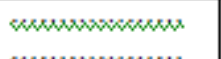 & 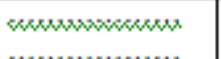 & $\operatorname{senses}$ & 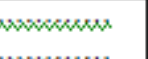 & & 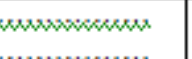 & $\operatorname{sensus}$ & massess & $\operatorname{sinsess} x$ & сxнsus \\
\hline & $\begin{array}{l}\text { () Olumlu } \\
\text { () Etkisiz } \\
\text { () Olumsuz }\end{array}$ & $\begin{array}{l}\text { () Olumlu } \\
\text { () Etkisiz } \\
\text { () Olumsuz }\end{array}$ & $\begin{array}{l}\text { () } \mathrm{Ol} \\
\text { () } \mathrm{Et} \\
\text { () } \mathrm{Ol}\end{array}$ & $\begin{array}{l}\text { lumlu } \\
\text { lkisiz } \\
\text { lumsuz }\end{array}$ & & $\begin{array}{l}\text { Olumlu } \\
\text { Etkisiz } \\
\text { Olumsuz }\end{array}$ & $\begin{array}{l}\text { () Oln } \\
\text { () Etb } \\
\text { () } \mathrm{Oln}\end{array}$ & $\begin{array}{l}\text { Imlu } \\
\text { cisiz } \\
\text { Imsuz }\end{array}$ & $\begin{array}{l}\text { () Olu } \\
\text { () Etki } \\
\text { () Olu }\end{array}$ & $\begin{array}{l}\text { alu } \\
\text { iz } \\
\text { asuz }\end{array}$ \\
\hline
\end{tabular}

